\title{
Molecular Diagnosis of Helicobacter Pylori Strain by 16S rDNA PCR Amplification and Direct Sequencing
}

Hirendra nath Banerjee*, Monique Gramby and Zack Hawkins

Department of Biological Sciences, Elizabethcity State University under, The University of North Carolina, Elizabethcity, NC-27909, USA

\author{
Abstract \\ Aim: Rapid detection of H.pylori strains by PCR-Sequencing. \\ Methods: $16 \mathrm{~S}$ rDNA amplification by PCR from template genomic DNA,confirmation of amplicon size by agarose \\ gel electrophoresis, sequencing of amplicons by automated sequencer,analysis of sequences by NCBI -BLAST \\ software.
}

Results: The PCR -Sequencing and analysis of the sequence data by BLAST resulted in detection of the strain to be of H.pylori strain\#26695.

Conclusion: The pathogenicity of H.pylori depends on the strain of the bacteria, PCR-Sequencing and analysis of the sequence data by BLAST can be a very quick and useful diagnostic method of the pathogen.

Keywords: Pcr; DNA sequencing; BLAST; H.pylori

\section{Introduction}

There is an increasing demand worldwide for the application of intelligent, fast and inexpensive measurement systems in clinical diagnosis. In the field of Clinical Microbiology, current techniques generally require $24-48$ hours to identify and characterize a pathogenic microorganism following a series of biochemical tests. Although new molecular biological and serological test have been introduced recently, they still have not replaced cultural methods and microscopy. Increased capital costs, need of highly skilled personnel and contamination, reduces the efficiency of these methods in the diagnosis of diseases like H.pylori infection and Tuberculosis [1,2]. Sequence analysis of the $16 \mathrm{~S}$ ribosomal RNA gene has been raised as possible mean of bacterial identification, which may circumvent some of these difficulties [3-5].

The infection by H.pylori produces a superficial chronic gastritis, which can develop to Peptic Ulcer Disease, Gastric and Duodenal ulcer. In recent years it was found that $H$.pylori infection may play a role in the early stage of the sequence:atrophic gastritis, intestinal metaplasia, dysplasia, and gastric cancer. The relation between H.pylori infection and cancer is so close that in 1994, in the United States, the international Agency for Research in Cancer as well as the World Health Organization considered these bacteria as the most important causative agent of cancer clarifying it as a class 1 carcinogen.

Until now, several invasive methods have been used in the diagnosis of gastric infection produced by H.pylori: histology, culture, rapid Urea breath test but none of them are considered as a reference standard [6]. We present in this study a molecular approach for H.pylori detection in which the primary identification of the causative agent was accomplished by using broad range primers to amplify part of the $16 \mathrm{~S}$ rDNA gene followed by sequencing of the amplicon and database search.

The routine clinical use of this technology appears feasible and this procedure could be used as a prototype for nucleic acid based amplification method for H.pylori detection.

\section{Material and Methods}

Genomic DNA of two strains of H.pylori, Strain ATCC \# 700824D and 70039D were purchased from American type culture collection
(ATCC), Manassas, VA, USA. 16S rDNA was amplified with the universal bacterial primers [5];

\section{Forward: 5' AGA GTT TGA TCC TGG CTC AG3'}

\section{Reverse: 5’ AAG GAG GTG ATC CAG CCG CA3’}

PCR reactions included $2.5 \mathrm{mMol} / \mathrm{L}$ dNTPs, $0.75 \mathrm{~mol} / \mathrm{L} \mathrm{MgCl} 2$, $1 \mathrm{nMol} / \mathrm{L}$ primers (Forward and Reverse) and 2.5 units Taq in PCR buffer (Gibco/BRL, Gaithersburg, MD,USA). PCR tubes were heated at $94^{\circ} \mathrm{C}$ for $45 \mathrm{~s}, 59^{\circ} \mathrm{C}$ for $60 \mathrm{~s}$ and $72^{\circ} \mathrm{C}$ for $90 \mathrm{~s}$ in a Perkin Elmer DNA thermalcylcer. After 28 cycles, the primer extension period $\left(72^{\circ} \mathrm{C}\right)$ was maintained for $7 \mathrm{~min}$.

The DNA was sequenced by an automated DNA sequencer using the 5 ' forward primer.

The resultant sequences were analyzed by NCBI-NIH BLAST search program for homology.

\section{Results}

A $1.5 \mathrm{~kb}$ amplification product was obtained from both the strains Figure 1. Partial sequencing of the amplicons was performed on an Applied Biosystems (373A) automatic sequencer using the 5' Forward primer. The DNA sequences obtained were subjected to BLAST search (NCBI, USA) for sequence homology and showed high percentage of homology with $16 \mathrm{~S}$ rDNA of H.pylori strain 26695. The sequences were reported to the GENBANK, and were accepted with annotation numbers: AY 057935 and AY057936.

${ }^{*}$ Corresponding author: Dr. Hirendra nath Banerjee,Associate Professor, Biological Sciences Department, Elizabeth City State University, University of North Carolina, 1704 Weeksville Road, Elizabethcity, NC-27909, USA, E-mail: bhirendranath@mail.ecsu.edu

Received August 23, 2011; Accepted October 17, 2011; Published October 19 2011

Citation: Banerjee HN, Gramby M, Hawkins Z (2011) Molecular Diagnosis of Helicobacter Pylori Strain by 16S rDNA PCR Amplification and Direct Sequencing. J Bioprocess Biotechniq 1:105e doi: 10.4172/2155-9821.1000105e

Copyright: (c) 2011 Banerjee HN, et al. This is an open-access article distributed under the terms of the Creative Commons Attribution License, which permits unrestricted use, distribution, and reproduction in any medium, provided the original author and source are credited. 
Citation: Banerjee HN, Gramby M, Hawkins Z (2011) Molecular Diagnosis of Helicobacter Pylori Strain by 16S rDNA PCR Amplification and Direct Sequencing. J Bioprocess Biotechniq 1:105e doi: 10.4172/2155-9821.1000105e

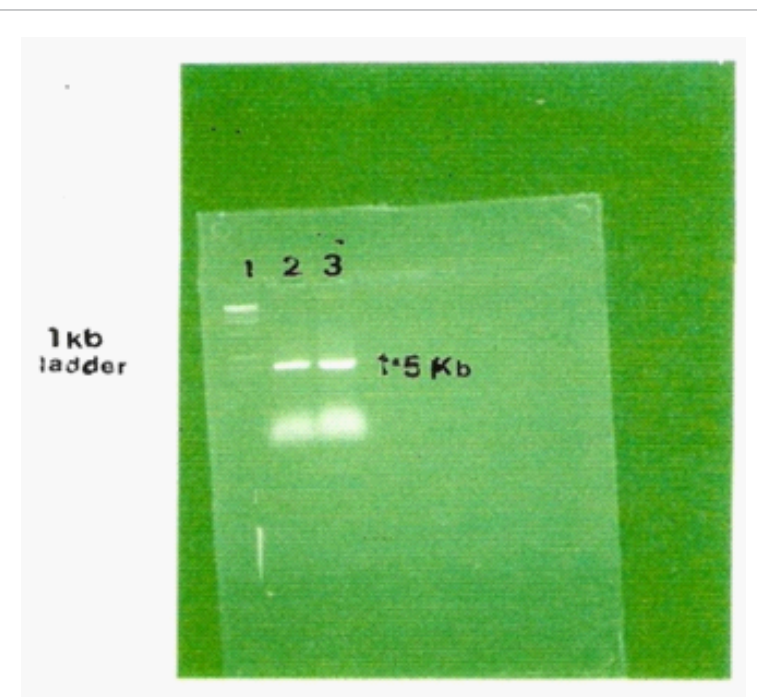

$1 \%$ Agarose gel showing $1.5 \mathrm{~kb}$ PCR amplicon obtained from both the Patient sample genomic DNA.

Lane1: $1 \mathrm{~kb}$ ladder

Lane2 : $1.5 \mathrm{~kb}$ amplicon from Patient 1

Lane3: $1.5 \mathrm{~kb}$ amplicon from Patient 2.

Figure 1: Gel-photograph.

\section{Discussion}

PCR technology provides potential for a powerful diagnostic tool in detection of pathogenic microorganisms. A number of studies over the last ten years have employed broad range primers, such as those to the $16 \mathrm{~S}$ rDNA genes, which can be used to detect most bacterial species. Similar with the conventional culture methodology, a molecular approach is as good as the specimen submitted and greater than the DNA database available. As of January 2000, the $16 \mathrm{~S}$ rDNA sequences in the Ribosomal Database Project (RDP II) represents 2,460 different bacterial species [7-9]. In this study we have shown a rapid mean of identification and differentiation of two strains of H.pylori bacteria based on their $16 \mathrm{~S}$ rDNA gene sequences. Since laboratory diagnosis of H.pylori by the existing methods has still less specificity and also it is difficult to diagnose re-infection, this method of detection by $16 \mathrm{~S}$ rDNA could be a useful alternative. There are several potential advantages to $16 \mathrm{~S} \mathrm{rDNA}, \mathrm{PCR}$ and sequencing. The technique is extremely sensitive and can detect DNA from a single infectious agent. Results can be obtained rapidly, unlike culture, which takes days to weeks. Therefore this technique is useful in clinical situations in which conventional microbiologic tests are too insensitive and slow or too cumbersome to be used on a large scale such as H.pylori detection. The pathogenicity of H.pylori depends on the strain of the bacteria, PCR-Sequencing and analysis of the sequence data by BLAST can be a very quick and useful diagnostic method of the pathogen

\section{Acknowledgment}

This research was supported in part by the Ronald McNair's Summer Scholarship to M. Gramby; NSF-EPSCOR Subcontract grant\#DTD42501 and NASA grant\#NAG-12554 to $\mathrm{H}$. Banerjee. The institutional EARDA grant from NIH\#G11HD 34280-05. The authors are grateful to Dr. G.Harmon, Dr. R. Blackmon, and M. McDaniels for their support and helpful suggestions and Dr.A.Alikhan,co-ordinator of EARDA program.

\section{References}

1. Anderson B, Sims K, Regnery R, Robinson L, Schmidt MJ, et al. (1994) Detection of Rochalimaea henselae DNA in Specimens form Cat Scratch disease patients by PCR. J Clin Microbiol 32: 942-948.
2. Avidor B, Kletter Y, Abulafia S, Golan Y, Ephros M, et al. (1997) Molecular diagnosis of Cat Scratch Disease: a two step approach. J Clin Microbiol 35: 19241930.

3. Drancourt M, Moal V, Brunet P, Dussol B, Berland Y, et al. (1996) Bartonella (Rochalimaea) quintana infection in a seronegative hemodialyzed patient. $J$ Clin Microbiol 34: 1158-1160.

4. Goldenberger D, Künzli A, Vogt P, Zbinden R, Altwegg M (1997) Molecular diagnosis of bacterial endocarditis by broad range PCR amplification and direct sequencing. J Clin Microbiol 35: 2733-2739.

5. Lane DJ, Pace B, Olsen GJ, Stahl DA, Sogin ML,et al. (1985) Rapid determination of $16 S$ ribosomal RNA sequences for Phylogenteic Analysis. Proceedings of the National Academy of Science USA 82: 6955-6959.

6. Maidak BL, Cole JR, Lilburn TG, Parker CT Jr, Saxman PR, et al. (2000). The RDP ( Ribosomal Database Project) Continues. Nucleic Acid Res 28: 173-174.

7. Ohara-Nemoto Y, Tajika S, Sasaki M, Kaneko M (1997) Identification of Abiotrophia adiacens and Abiotrophia defectiva by $16 \mathrm{~S}$ rRNA gene PCR and restriction fragment length polymorphism analysis. J Clin Microbiol 35: 2458-2463.

8. Relman DA, Loutit JS, Schmidt TM, Falkow S, Tompkins LS (1990) The agent of bacillary angiomatosis. An approach to the identification of uncultured pathogens. N Engl J Med 6: 1573-1580.

9. Sleigh J, Cursons R, La Pine M (2001) Detection of bacteraemia in critically ill patients using $16 \mathrm{~S}$ rDNA polymerase chain reaction and DNA sequencing Intensive Care Med 27: 12691273. 